\title{
Miradas urbanas del profesorado iberoamericano desde la cultura visual
}

\section{Resumen}

Nos interesa conocer si hay una mirada propia del profesorado hacia la realidad urbana. Partimos de descripciones tanto verbales como visuales, mediante imágenes y textos. La investigación se ha desarrollado en Santiago de Chile, Valencia, Lima, Medellín, Montevideo y Buenos Aires, y combina acciones participativas directas con entrevistas personales. La metodología es mixta y parte de un estudio de caso que se complementa con la investigación basada en las artes. Comprobamos que sí hay una mirada particular del colectivo docente hacia su propia ciudad, cargada de reflexión crítica. Se trata de un tema poco abordado que precisa mayor atención.

\section{Palabras clave}

Docentes; ciudad; cultura visual; pedagogía crítica; creatividad; imagen

Para citar este artículo / To cite this article / Pour citer cet article / Para citar este artigo Huerta, Ricard (2018). Miradas urbanas del profesorado iberoamericano desde la cultura visual. magis, Revista Internacional de Investigación en Educación, 10 (21), 55-76. DOI: 10.11144/Javeriana.m10-21.mup 
Keywords

Teachers; city; visual culture; critical pedagogy; creativity; image

\section{Mots clés}

Enseignants ; ville ; culture visuelle ; pédagogie critique ; créativité ; image
Abstract

We are interested in knowing if there is a proper view of the teaching staff towards the urban reality. We start with verbal and visual descriptions, through images and texts. The research has been developed in Santiago de Chile, Valencia, Lima, Medellin, Montevideo and Buenos Aires, and combines direct participatory actions with personal interviews. The methodology follows a mixed method and is based on a case study that is complemented by research based on the arts. We concluded that there is a particular view of the teaching group towards their own city, which is full of critical reflection. This is a topic that has been little addressed and needs more attention.

\section{Résumé}

On a l'intérêt de savoir s'il y a un regard propre des enseignants envers la réalité urbaine. On part des descriptions tantôt verbales que visuelles, à travers les images et les textes. La recherche a été faite à Santiago du Chili, Valencia, Lima, Medellin, Montevideo et Buenos Aires, cette recherche combine les actions participatives directes avec les entretiens personnelles. La méthodologie est mixte, elle part d'une étude de cas qui s'est complété avec la recherche basée en Arts. On a confirmé qu'il y a un regard particulier du collectif des enseignants envers leur propre ville, chargée de réflexion critique. II s'agit d'un sujet peu abordé qui requière plus d'attention.

\section{Palavras-chave}

Docentes; cidade; cultura visual; pedagogia crítica; criatividade; imagem

\section{Resumo}

Interessa-nos conhecer se há um olhar próprio do professorado sobre a realidade urbana. Partimos de descrições tanto verbais como visuais, mediante imagens e textos. A pesquisa se desenvolveu em Santiago do Chile, Valência, Lima, Medellín, Montevideo e Buenos Aires, e combina ações participativas diretas com entrevistas pessoais. A metodologia é mista e parte de um estudo de caso que se complementa com a pesquisa baseada nas artes. Comprovamos que há um olhar particular do coletivo docente sobre sua própria cidade, carregado de reflexão crítica. Trata-se de um tema pouco abordado que precisa maior atenção. 


\section{Introducción}

Como profesionales de la educación, estamos conscientes de la importancia que ostenta el modelo organizativo y vital que denominamos ciudad. Desarrollamos un deseo de indagar en todo lo concerniente a la cultura urbana, algo que asumimos como una verdadera reivindicación, ya que somos responsables de transmitir estos parámetros de responsabilidad y conciencia cívica a nuestro alumnado. Nos preocupan los abusos urbanísticos, repudiamos la falta de equidad en el reparto de bienes y posibilidades, y nos inquietan los excesos en los que derivan las especulaciones inmobiliarias o la mínima sensibilidad hacia las opciones divergentes de colectivos minoritarios o minorizados (Belil, Borja \& Corti, 2012). Debido a la deriva crítica que generamos en las observaciones, optamos por analizar y conocer mejor nuestro entorno, y lo hacemos compartiendo intereses con otros colectivos (arquitectos, urbanistas, sociólogos, antropólogos, historiadores, artistas, escritores). Coincidimos con gente que analiza el entorno urbano desde la posibilidad de acercamiento al hecho cultural, lo cual incluye en realidad todo lo relativo a la experiencia humana (Errázuriz, 2006; Lynch, 1998). Desde esta óptica crítica, elaboramos el presente discurso docente y revisamos una verdadera tradición de autores que teorizan sobre lo urbano (Benjamin, 2005; Codeluppi, 2014; Maffesoli, 2000), al tiempo que suscribimos una tendencia que consiste en valorar al profesorado como un colectivo capaz de transformar en positivo las reglas del juego (Duncum, 2008; Huerta, 2015; Robalino-Campos, 2014; Stenhouse, 1987). Cuando hablo de docentes, me refiero a un amplio espectro que abarcaría todos los grupos y niveles de profesorado (desde docentes de infantil hasta profesores de universidad). Pero debido a nuestra adscripción profesional, en las investigaciones domina el interés por un perfil que incluye a maestros y maestras de enseñanzas obligatorias.

En lo relativo a hibridaciones metodológicas que permiten los nuevos escenarios que ocupamos desde la cultura visual (Rose, 2016; Sassen, 2011), sin perder de vista las posibilidades que ofrece la mirada antropológica (Edwards, 2014; Morphy \& Perkins, 2006), cabe incidir en el ambiente desprejuiciado y participativo que planea sobre las nuevas prácticas que se vienen implementando en educación artística. En ese sentido, para Leda Maria Barros de Guimarães (2017), resulta fundamental atender determinadas ideas y concepciones que se han instalado, ya que vamos buscando

caminos metodológicos en la investigación en arte y cultura visual, tales como: cruzar márgenes y fronteras disciplinares persiguiendo nuevos sentidos en la producción de conocimiento, trabajar con espacios (teóricos y prácticos) cruzados y negociados, ejercitar múltiples escrituras, reconocer y mapear identidades culturales deslocalizadas y en proceso de deslocalización, etc. (Guimarães, 2017, p. 139)

Esto nos remite también a la idea de celebración de la VCAE (Visual Culture Art Education), todo un programa de atención a la visualidad como ejercicio docente y discente, desde posicionamientos que dan paso a la reflexión, al hurgar en cuestiones importantes como la capacidad reflexiva, utilizando elementos que surgen desde la filosofía, la estética, la sociología o la historia, y que están atentos a la implicación social y política de los propios docentes (Duncum, 2008).

La idea de lo urbano evoluciona del mismo modo que lo hace el concepto de ciudad. En nuestro caso, se elabora desde una doble adscripción que funciona entre lo patrimonial y lo identitario, y se urde así una manera
Descripción del artículo | Article description | Description de l'article | Artigo descrição

Este artículo de investigación se deriva del proyecto "Educación Patrimonial en España: Consolidación, evaluación de programas e internacionalización del Observatorio de Educación Patrimonial en España (OEPE)". Este trabajo supone un acercamiento desde la metodología de los estudios de caso a la imagen que de su propia ciudad tienen los colectivos docentes de distintos países. Incluye una recogida de datos tanto a partir de declaraciones verbales como desde el análisis de imágenes realizadas por los propios docentes. 
de pensar el espacio y la historia mediante lo que ocurre entre las personas, un linde provocador, un patrimonio migrante (Huerta \& De la Calle, 2013), en el cual encaja un elocuente relato de la ciudadanía. Se trata de conocer si realmente hay una mirada particular y propia del colectivo docente hacia lo urbano, para lo cual utilizamos un planteamiento de trabajo ambientado en los estudios culturales y recurrimos a las estrategias de investigación propias de los estudios de caso (Stake, 1998); implicamos en la recogida de datos a un número concreto de participantes y destacamos las pautas que esgrime la cultura visual (Huerta, 2014; Walker \& Chaplin, 2002). Animamos al profesorado a producir imágenes y partimos de los resultados que generan para establecer nuestro análisis.

Las realidades geográficas y culturales de los países en los que se ha realizado el estudio son diferentes y diversas. Pero también hay líneas de vecindad que establecen auténticos paralelismos entre los intereses y las necesidades que afectan al conjunto de docentes de todos estos lugares. De hecho, el concepto mismo de ciudad se elabora de manera similar, pues hay un territorio común desde el cual se verifica la acción educativa (Muntañola \& Muntañola, 2011; Ordine, 2013). Uno de los retos que plantea el presente estudio es justamente la posibilidad de acercar las realidades educativas de varios países, con el fin de desentrañar los rasgos comunes, de manera que estas semejanzas nos permitan hablar de un colectivo docente más allá de las fronteras, de los estándares curriculares o administrativos, y de los límites legislativos (Giroux, 1990; MartínezBonafé, 2014).

Intentamos acercarnos a realidades sociopolíticas complejas desde ámbitos poco favorecidos, como pueden ser el arte o la educación artística, lo cual nos obliga a replantearnos lo que Pierre Bourdieu delimita como lógica de la investigación (LDI); a este respecto, leemos en Guillermo Bustamante-Zamudio que

\footnotetext{
la LDI desmonta el escenario de buenos y malos: quienes investigan científicamente lo social desvelan verdades de ese mundo (muchas de las cuales no gustan a algunos de los que buscan, por la vía de los buenos propósitos); y los que no hacen suficiente investigación científica social, hacen consistir la visión dominante, aunque digan lo contrario. (Bustamante-Zamudio, 2016, p. 57)
}

Nuestro rumbo atañe preferentemente a lo social desde las innovaciones educativas; desde esta predilección por lo social enlazamos con la cultura visual (Masschelein, 2006).

Si bien la investigación que ahora se presenta ha sido realizada con profesorado (de diferentes especialidades, edades, condiciones sociales, culturales y geográficas), transmitimos la posibilidad (y la urgencia) de que el alumnado cree también sus propias imágenes para redescubrir la ciudad en la que vive. De este modo, introducimos la investigación basada en artes en las prácticas habituales del aula, lo cual conlleva un atractivo especial para el propio alumnado, que cada día genera numerosas fotografías y las difunde al instante por internet. Se trata, en última instancia, de que aquellas prácticas que son realizadas inicialmente por el profesorado se transmitan después al alumnado en talleres en los que la imagen (fotografía, video) tenga una presencia destacada.

\section{Metodología}

El marco metodológico en el que se basa nuestra investigación es de carácter cualitativo y se ambienta en los estudios de caso (Hubard, 2008; Stake, 1998). La forma de abordar la cuestión consiste en ofrecer a los maestros participantes un primer encuentro de carácter performativo, para que vean más atractiva la propuesta, y así puedan favorecer una mayor implicación des de la complicidad y la franqueza. El ambiente distendido fomenta respuestas sugerentes, todo ello mediante 
el uso de propuestas creativas y artísticas, e impulsa el empleo de procedimientos artográficos (Irwin \& O'Donoghue, 2012). A partir de las acciones iniciales y de las reflexiones que estas permiten, se plantea un conjunto de preguntas mediante un cuestionario. Además de explicar por escrito sus opiniones, se les pide a los docentes participantes que realicen imágenes de su ciudad. El profesorado fotografía aquellos entornos que más le interesan, y de este modo generamos también la creación gráfica, lo que fomenta el uso de imágenes, en línea con lo que denominamos investigación basada en las artes (Arts Based Research). Este sistema permite acercarnos a las opiniones del profesorado tanto por medio de sus respuestas como mediante su implicación directa en actividades de índole artística y performativa. Estas imágenes refuerzan la parte gráfica del estudio, ya que contamos con una documentación visual que aportan los propios docentes. Por tanto, se utilizan sus relatos como narrativas peculiares, elementos visuales de creación que nos ayudan a confeccionar un panorama amplio de lo que los docentes de diferentes lugares entienden por cultura urbana. Se intenta cubrir un espectro amplio de representatividad, al incluir entre los participantes a personas de diferentes edades, de adscripciones económicas y sociales diversas, integrando a hombres y mujeres, y contando con la colaboración de profesionales con variada experiencia en el aula. Se trata de generar un espíritu de colectivo, desde el cual lanzar una mirada compleja y rica, para evitar discriminaciones y sumar opiniones desde un espectro amplio de representatividad. Deseamos contribuir a reforzar la idea de los docentes como colectivo, animar al profesorado a generar puentes entre las diversas especializaciones, compartir así geografías y lugares comunes, y reunir esfuerzos para conseguir una mayor visibilidad y un mayor respeto.

Este modelo de estudios sobre la ciudad, sobre la capacidad ética y estética que se genera entre sus habitantes, debe mucho al trabajo de Francesco Careri, quien ha sabido generar con sus teorías un auténtico movimiento para reivindicar lo estético como enclave perfecto para el disfrute y conocimiento de lo urbano (Careri, 2002). Este autor ha repasado los movimientos artísticos desde los cuales se han impulsado este tipo de rituales, acciones que ahora valoramos y practicamos más allá de lo meramente estético, con extensiones sociales y políticas de alto calado cultural (Careri, 2014). Si desde el ángulo arquitectónico, urbanístico y artístico nos sentimos representados por las aportaciones de Careri, tanto desde la pedagogía (Alderoqui, 2012; Huerta, 2012; Planella-Ribera, 2014) como desde la literatura (Calvino, 2010; Pamuk, 2009), las muestras de acercamiento a lo urbano que posibilitan un encuentro con lo educativo están habitualmente impregnadas de sesgos creativos, algo que resulta muy familiar a los investigadores del territorio de la estética (Laddaga, 2006; Romano, 2008). Al unir componentes de diferentes procedencias académicas, conseguimos un dominio complejo que permite vincular los intereses del profesorado, recopilar datos que van desde sus opiniones escritas hasta sus deseos y proyecciones en forma de imágenes. También tenemos en cuenta las aportaciones de Bernardo Bustamante-Cardona (2016) cuando habla de una cuarta ruta desde la epistemología de los saberes, del saber artístico y educación artística. Esta ruta está poco explorada, pero es pertinente para dar a entender los cambios que ocurren en los saberes, y en este caso atiende el devenir intrínseco del saber pedagógico y del arte desde el punto de vista de la organización conceptual y el método, y hace énfasis en la pregunta por la posibilidad de un saber, de sus condiciones de formación y sobre todo de la condición paradigmática que define. Añade el autor que

son pocos los análisis en Colombia sobre la ruta epistemológica en este campo teórico, y se espera por lo tanto una emergencia que permita cualificar los aspectos de interdisciplinariedad de la educación artística y de la articulación de las diferentes rutas, en un panorama complejo. (Bustamante-Cardona, 2016, p. 159) 


\section{Mirar e interpretar la propia ciudad}

Desde un posicionamiento de reivindicación social, Jaume MartínezBonafé repasa las numerosas opciones educativas que la ciudad posibilita al detectar que "la ciudad es también un aula viva en la que se aprende la protesta", incluso "un laboratorio de ciudadanía en el que se ensayan posibilidades de encuentro y relación diferentes". Al indagar entre las múltiples opciones de ocupación del espacio público por parte de la ciudadanía, el autor revela que en realidad "las protestas ciudadanas y los movimientos sociales que las articulan nacen del conflicto político sobre un modo de entender y querer vivir la ciudad" (Martínez-Bonafé, 2014, p. 82). La ciudad también es un enclave de agitación cultural y de acción política, lo cual repercute en un mayor desarrollo de la siempre necesaria lucha por los derechos humanos y de las actividades que evidencian una auténtica innovación en todos los ámbitos de la comunicación humana. Estas facetas deben ser desarrolladas por cada docente, con el fin de aprender y disfrutar de las posibles lecturas de la ciudad, aprendiendo a manejar los dispositivos de cada uno de los elementos que la delimitan y la construyen. Además, la ciudad se escribe, relata su alegato en defensa de nuevas opciones de convivencia y respeto por la diversidad. La ciudad es un ente articulado, y puede combinar particularidades inicialmente muy diferentes entre sí (Barreira \& Mattos, 2014).

La curiosidad constituye una potente motivación y como docentes hemos de ser curiosos. En el entorno urbano, negociamos constantemente con la curiosidad. Cualquier lugar de la geografía urbana (una tienda, un museo, un supermercado, un jardín, un cine, una facultad, un solar abandonado, un autobús) permite despertar interés hacia una disposición para ser interpretado. En las acciones, animo al profesorado a observar y a diseccionar los diferentes espacios de la ciudad, para generar una actitud crítica basada inicialmente en la observación. Posteriormente, les aconsejo procesos técnicos y estilísticos adecuados para que confeccionen un discurso propio a partir del estímulo que esta observación ha generado. De este modo, surgen las imágenes de la ciudad, las cuales son analizadas al tomar decisiones como qué elementos son fotografiados y cuáles no, cuáles son sus lugares preferidos, qué ángulo puede ser más propicio para componer la imagen, incluso si es conveniente o no manipular la fotografía con filtros o retoques. De esta manera, empezamos a gestionar una posible mirada docente hacia lo urbano con base en la producción de imágenes confeccionadas por el profesorado. Además, este es un buen punto de inflexión para reflexionar críticamente sobre los motivos por los cuales nos gusta o no el lugar en el que vivimos y trabajamos.

\section{Del Mediterráneo al Atlántico}

El barrio del Cabanyal, una zona marítima de Valencia, sufrió el acoso del gobierno municipal, que amenazaba con desequilibrar el ritmo peculiar del lugar. La lucha de los vecinos del Cabanyal por mantener viva la estructura tradicional del barrio ha durado más de veinte años, lo que provocó una serie de acciones que pusieron en jaque al partido que gobernaba la ciudad en ese lapso (1991-2015). Destacan en ese sentido las sucesivas ediciones de Cabanyal Portes Obertes, un potentísimo esfuerzo organizativo consistente en utilizar las casas particulares de los habitantes del barrio para convertirlas en espacios expositivos abiertos al público, intervenidos por artistas de diferentes países. Con este tipo de gestos, el Cabanyal ha tomado relevancia internacional, aunque no se ha podido 
paralizar el derrumbe de numerosas casas y edificios. El profesorado valenciano ha decidido tomar este barrio como motivo para sus fotografías, además de incluir como tema la huerta cercana, también amenazada por las construcciones de edificios. Los docentes recuperan estos vestigios de la lucha vecinal y fotografían la zona vecina al mar. También se interesan por los lugares de paseo.

Fotos 1,2 y 3

Imágenes de Valencia tomadas por docentes valencianos
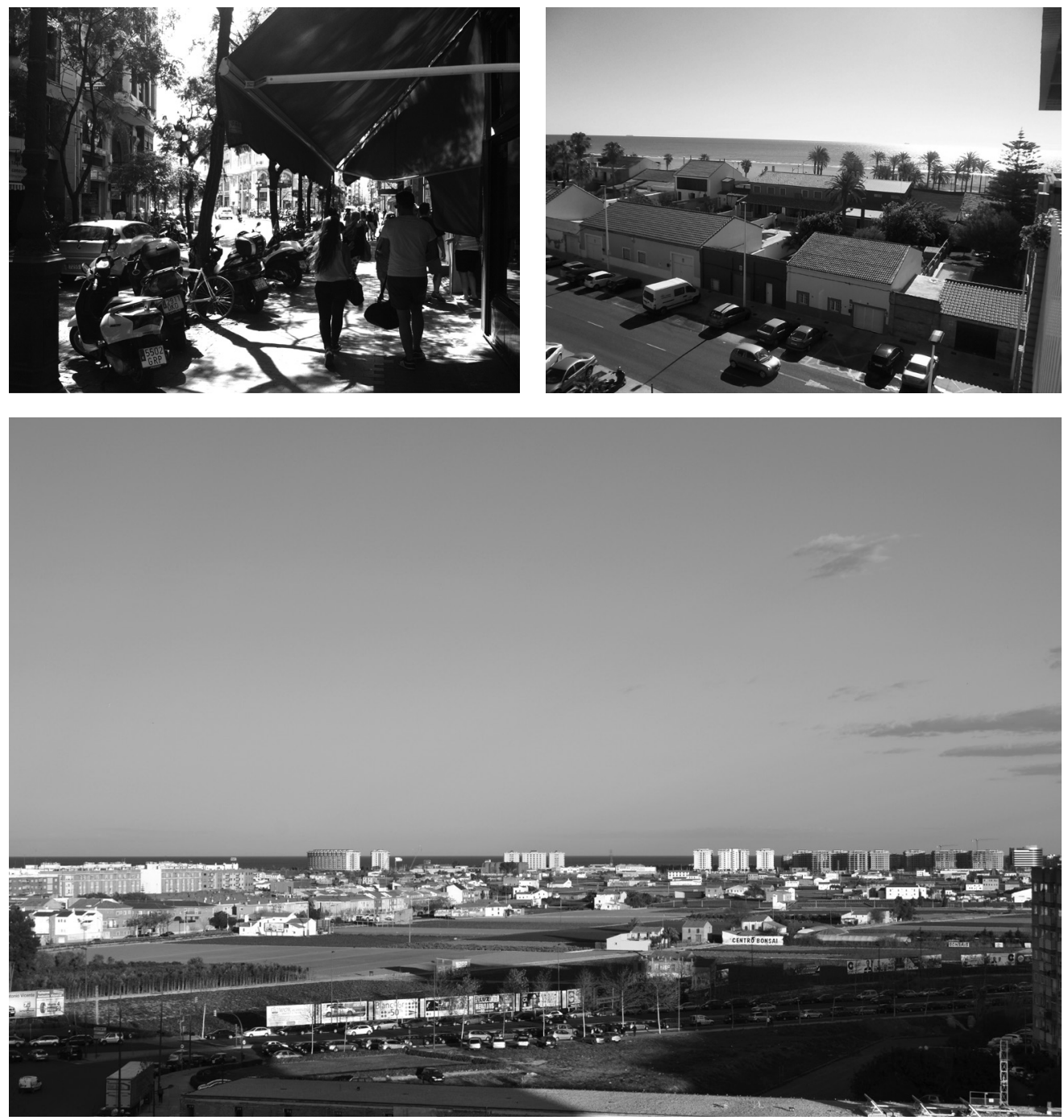

Fuente: Ricard Huerta, Julián Otero y Nacho Igual. Destacamos que no han buscado los lugares turísticos ni tampoco los entornos patrimoniales habituales, sino que eligen espacios propios del compromiso social.

A Valencia le ocurre algo similar a lo que sucede en tantas ciudades occidentales, algo que denuncia Richard Sennett cuando afirma que "gran parte de la planificación urbana del siglo XX respondía a este principio: derriba todo lo que puedas, arrásalo y luego construye a partir de cero" (Sennett, 2013, p. 263). Los primeros años del siglo XXI vinieron marcados 
por la exageración en los planes urbanísticos, las arquitecturas abultadas y poco eficientes, y por la corrupción política en el nivel más alto. A pesar de las locuras que propiciaron todos estos disparates, tanto los movimientos vecinales de barrio como las organizaciones no gubernamentales de diferente adscripción han venido potenciando acciones artísticas y reivindicativas en barrios como el Cabanyal, Ciutat Vella o Russafa. De hecho, para el profesorado lo más importante no son las arquitecturas fastuosas y espectaculares, sino los ritmos tranquilos que imprimen los lugares más íntimos. Una docente define Valencia con las palabras "luz, cálida, Ilana", lo que incide en los tres aspectos que más le gustan "clima, huerta, comida"; aquellos que le molestan y disgustan son "gobierno, cultura, inundaciones". Entre los lugares preferidos del profesorado valenciano hay espacios naturales y también elementos urbanísticos: "el paseo marítimo, su amplitud, el olor del mar y la tranquilidad que ofrece"; "la Malvarrosa a primera hora de la mañana con suave brisa de levante"; "la Albufera, humedal costero de gran belleza con aves acuáticas"; "la zona norte, donde se vislumbra el espacio de la huerta"; "el parque Gulliver, que desproporciona las dimensiones habituales y permite relajarse, divertirse y jugar"; "la plaza de la Virgen"; "el barrio del Carmen"; "la Lonja" y "la actividad comercial de un domingo en la Plaza Redonda"; "el Mercado Central"; "la plaza de San Nicolás". Entre las opciones destaca lo sencillo, aunque en algunos casos aparece el carácter un tanto barroco que identifica a lo valenciano, algo que puede advertirse si observamos los suntuosos vestidos de fallera o la propia fiesta de Las Fallas, dominada por una estética abigarrada. Pero lo que más llama la atención a la mayoría de docentes es el Jardín del Turia, que se convierte en el tema preferido en las fotografías y el aspecto más comentado en los cuestionarios. Y es que "el antiguo cauce del Turia, reconvertido en parque verde que recorre toda la ciudad" es un verdadero pulmón de la ciudad, un espacio en el que la gente pasea, hace deporte, lee, toma el sol, juega con los niños. Los más jóvenes no están conscientes de que este antiguo cauce del río es ahora una zona verde para toda la ciudadanía, porque en la década de 1970 hubo numerosas manifestaciones ciudadanas a favor de esta opción', frente a otros proyectos urbanísticos que hubiesen supuesto la construcción de edificios y autopistas. Por tanto, la ciudadanía fue la que realmente exigió este espacio público que ahora disfrutamos y apreciamos todos. La memoria histórica debe convertirse en un elemento clave en las aulas, para fomentar la conciencia crítica y exigir tanto el reconocimiento de los hechos como el respeto a las personas que lucharon por lo que hoy tenemos (Pariser, Castro \& Lalonde, 2016).

Una ciudad como Buenos Aires aporta los rasgos propios de las grandes urbes: marcados contrastes sociales, un ritmo de vida vertiginoso y muy exigente, altos niveles de competitividad, una gran oferta que no está al alcance de todos. La propuesta "La ciudad vista desde una mirada sensible de lo cotidiano" plantea qué se entiende por estética hoy y qué implican la estética y el arte en la realidad cotidiana de una escuela con la modalidad de intensificación en arte. El colectivo docente de la escuela decide trabajar con los conceptos de artisticidad y esteticidad. El barrio de Liniers es una zona limítrofe de Buenos Aires. Roberto es artista y docente

1 En 1958, una gran riada en Valencia provocó numerosas pérdidas humanas (decenas de muertos) y cuantiosas pérdidas materiales con infraestructuras destruidas. Durante la década de 1960 se hizo una importante obra de ingeniería que modificó el antiguo cauce y llevó el nuevo río hacia el sur de la ciudad. En 1970, se planeaba construir una autopista en lo que había sido el viejo cauce (ahora seco). La ciudadanía salió a la calle para reclamar un espacio para todos y en 1982 consiguió que el antiguo cauce se convirtiera en un espléndido jardín de 8 kilómetros de longitud. 
Fotos 4,5 y 6

Imágenes del Jardín del Turia tomadas por docentes
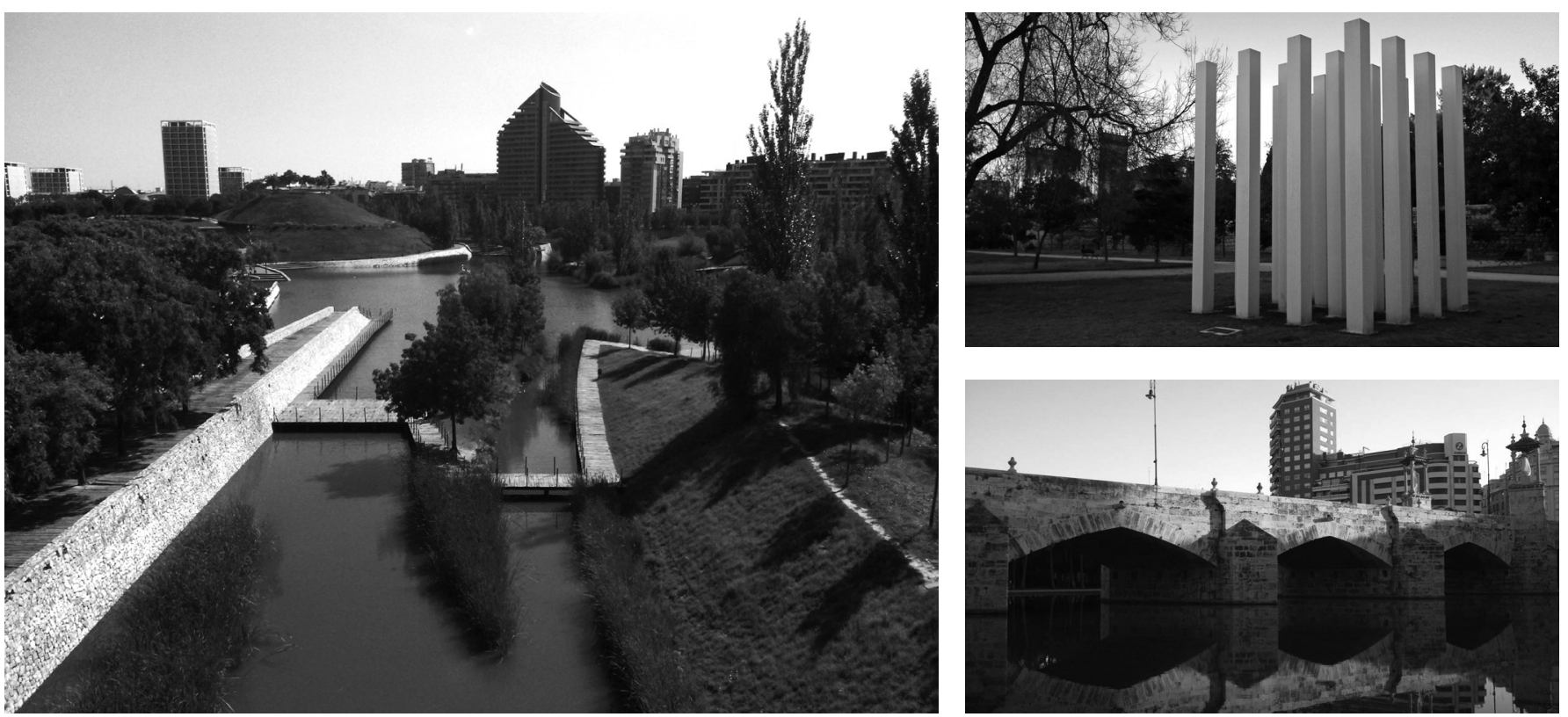

Fuente: María José Chisvert

David Martínez y Albert Palacios

de arte en esta escuela, participa activamente del proyecto de intensificación en arte que elabora los grandes murales en las paredes del centro, para acercar así la escuela a la gente de la calle, al tiempo que ayuda a insertarse en el barrio al alumnado de bellas artes. Ha elegido Buenos Aires como lugar para vivir, y cree que tanto como docente como en su faceta de artista tiene mucho para ofrecer y dar. Trabajar con la diversidad implica un reto en sí mismo. Para mejorar la institución educativa se requiere una fuerte toma de contacto con la realidad externa. Las distintas causas de marginación, política o económica, tan comunes en Latinoamérica, son también problemas de la escuela (Méndez-Rivera, 2016). Resulta indispensable un aprendizaje de la alteridad, por parte de todos y cada uno de los actores sociales, entendida como la aceptación del otro como sujeto pensante y autónomo. Teresa conoce bien estos límites urbanos, aunque ahora trabaja en un colegio céntrico, pero nos define la situación: "trabajar en la ciudad de Buenos Aires es como poder hacerlo en muchos lugares al mismo tiempo". La maestra Olga, que trabaja en el programa Huellas de la escuela, recupera el patrimonio histórico-educativo de la ciudad, recoge documentación, objetos que se hallan en las escuelas, mobiliario y todo aquello referido a la historia de la institución.

La escuela debe recuperar su capacidad reflexiva para pensar y ayudar a resolver la problemática que se genera en contextos turbulentos, y se compromete activamente para que sus alumnos no queden marginados del sistema ni segmentados dentro de él. Para responder a esta política de la memoria, la justicia y el conocimiento, la institución educativa debe ser tolerante y generadora de un espacio para la coexistencia de distintas formas de ver el mundo, al crear al mismo tiempo la necesidad y capacidad de fundamentar y argumentar cada una de estas distintas posturas. 
El proyecto - que ha lanzado el equipo de profesores de la Escuela No 4 Félix de Olazábal del barrio de Liniers en Buenos Aires - utiliza el arte para integrar sus esfuerzos en la línea de establecer un diálogo con la ciudad. Este diálogo debe estar basado en la confianza y es muy importante formar a la ciudadanía para que sea exigente en la reclamación de sus derechos. Marcela Pelanda, rectora de la Escuela Normal Superior en Lenguas Vivas No 1 Presidente Roque Sáenz Peña, de la ciudad de Buenos Aires, se formó como maestra, y se considera muy afortunada de "entregarse cada día a los otros". Ha ejercido la docencia en todos los niveles. Coordina una escuela de 3.000 alumnos, uno de los centros más importantes de la ciudad, y está consciente de que los modelos actuales están limitados ante los profundos cambios que se viven, y su desafío supone lograr una nueva escuela en la que profesorado y alumnado trabajan juntos.

Fotos 7, 8 y 9

Tres imágenes de Buenos Aires tomadas por docentes de la ciudad
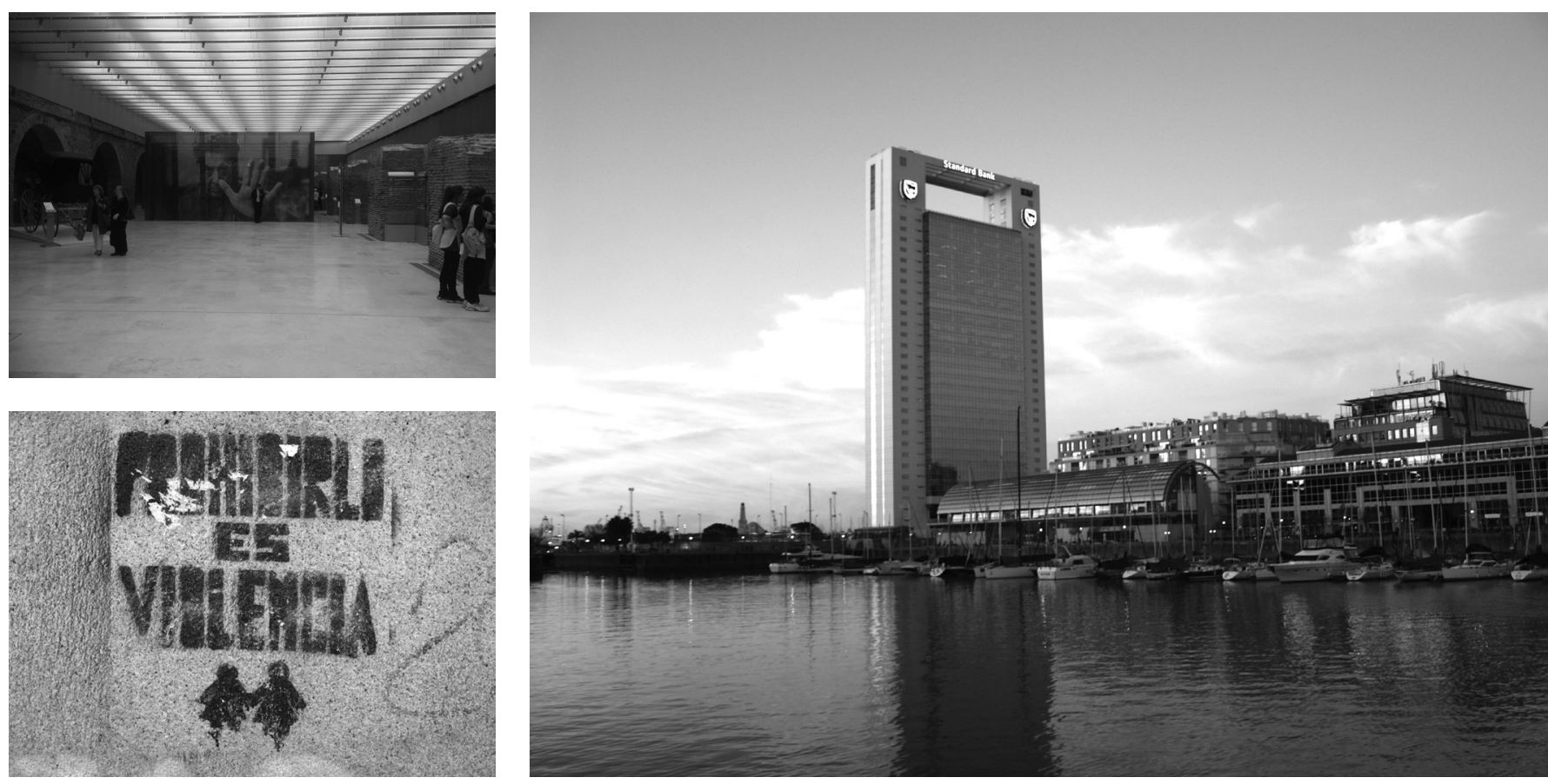

Fuente: docentes de Buenos Aires

Al definir Buenos Aires en las encuestas los docentes utilizan términos como "expandida, injusta, desigual, abierta, esquina, calles, encuentros, intensa, estimulante, inmensa, infinita, nostálgica y luminosa". Valoran positivamente que "es una ciudad que abre sus espacios y sus calles a quienes la visitan, donde la amistad se cultiva como un valor supremo y esto se ve en sus bares, plazas y calles. Es el reflejo de una historia compleja, de lucha de intereses y valores, es el reflejo de quienes vivieron y vivimos en ella. Su oferta cultural permanente, de teatros, exposiciones, espectáculos callejeros, ferias, danza, arte...". Encuentran arduo "tener que transitarla diariamente", ya que "tiene un ritmo de locos, acelerado, vertiginoso, todos corremos sin saber muy bien por qué". Se quejan de que "las políticas de derecha del 
gobierno de la ciudad han desmontado sus redes de solidaridad y asistencia institucional, por lo cual el estado municipal está desatendiendo sus deberes más básicos". Considero al colectivo docente bonaerense como uno de los más combativos del continente, y al valorar su papel como educadores en la formación de ciudadanía, dicho profesorado expone que "enseñar Buenos Aires propicia habitarla de manera reflexiva y emocional a la vez, e implica también luchar para que siga existiendo como un lugar para todos". Entienden que "es necesario detenerse, mirarla y conocerla para disfrutarla", ya que "Buenos Aires se habita en un fluir de hábitos y pasos apurados casi irreflexivos". Hay una preocupación constante por la educación de y en el espacio público. En las clases se reflexiona sobre la importancia, la construcción y el ejercicio de ciudadanía. Se problematiza la realidad y se plantean interrogantes, para promover que los estudiantes se sientan habilitados para expresar sus ideas, al generar debate y estimularlos a que escuchen las distintas voces.

Por su parte, Montevideo aguanta firme los vientos intempestivos, que en los meses de invierno hielan el ambiente, tal como asegura el profesorado que la define con las palabras "viento, frío, sombra", y con su "monocromática" austeridad, debido a la predominancia de nubes grises durante el período invernal, la ciudad se presenta durante una parte del año eminentemente sombría y monótona. No obstante, algunos de los docentes entrevistados inciden en que la ciudad es "inquieta" o "pintoresca" y añaden que la ven "llena de oportunidades", refiriéndose esencialmente a la rica oferta cultural y al hecho de que se trata de la ciudad más importante del país, entorno al que han llegado buena parte de quienes hace unas décadas poblaban las amplias zonas rurales dedicadas básicamente a la cría de ganado. Pero Montevideo también es la fuerza de sus trabajadores, de las luchas por la dignidad que han atravesado toda su historia reciente, y del poliédrico desenlace que generan las palabras y los argumentos de sus intelectuales y artistas. Según aseguran varios docentes encuestados, estamos hablando de una ciudad donde reina la "melancolía". Puede que la tranquilidad y el tedio se hayan apoderado desde siempre de Montevideo. El profesorado montevideano dispone de claras referencias en cuanto a preferencias en materia artística. Están muy pendientes de generar sus propias mitologías urbanas. La gran mayoría señala a Mario Benedetti como el escritor que mejor define la capital uruguaya, y eso teniendo en cuenta que Benedetti se vio forzado a exiliarse durante la dictadura. El escritor más admirado optó por el autoexilio en Madrid cuando terminó el régimen militar. Hay unanimidad al reconocer el rasgo de identidad tan genuino de la película Whisky (Rebella \& Stoll, 2004). Se trata de un extraordinario relato urbano aparentemente sosegado, como casi todo en Montevideo. Debido a la serenidad imperante, da la sensación de que la tranquilidad absorbe todo síntoma vital, y parece que la monotonía se apodera del ambiente. Otro de los filmes muy apreciados es El baño del Papa (Charlone \& Fernández, 2007), un verdadero ensayo social cuyo relato está ambientado en la frontera con Brasil. Una pieza de ficción muy animada que bien podríamos creer que se trata de un documental en el que se narran las peripecias de la población ilusionada por mejorar sus vidas a partir de la visita del Papa.

Fotos 10,11 y 12

Imágenes de Montevideo tomadas por profesores
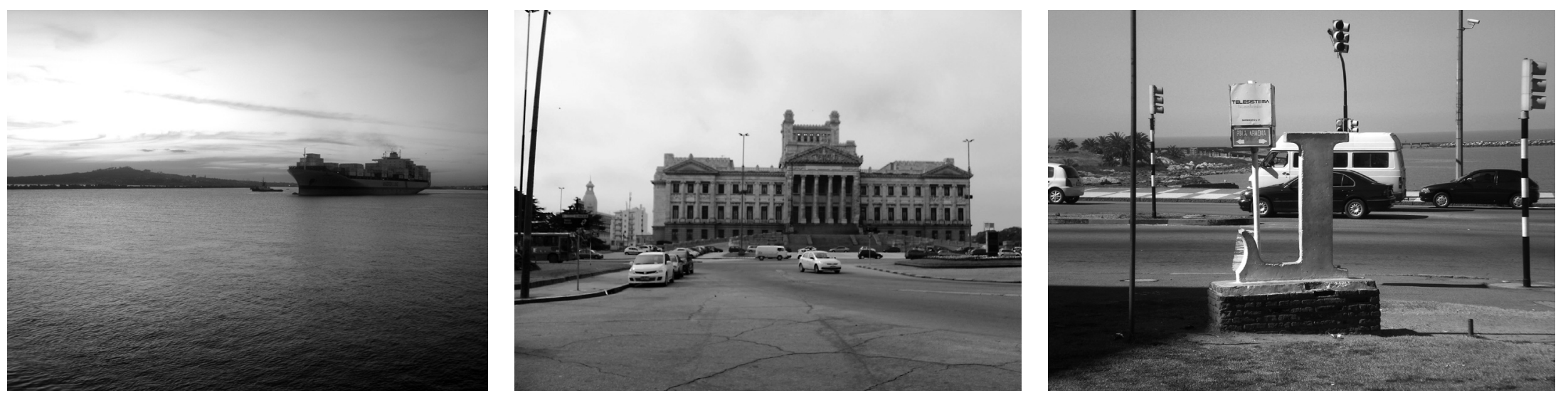

Fuente: Gladys Schiavone, Juan Menéndez y Zulaika Juambeltz 
Cuando hemos planteado a los docentes de Uruguay que indicasen un lugar de Montevideo que les resultase especialmente atractivo, prácticamente todos se decantan por la Rambla. En este país de larga tradición laica, la mayoría considera que el profesorado tiene un papel sumamente importante, ya que "corresponde a los fines de la educación formar seres autónomos, críticos, seres útiles para el Uruguay del futuro", a pesar de que "en este país no todos asumen que la docencia es una profesión y no un mero trabajo, y tal vez es por eso el papel del docente no es valorado y respetado por el resto de la sociedad". Se valora positivamente que "el sentido de pertenencia a un grupo genera lazos, promoviendo sinergias que fortalecen, consolidan su identidad y perpetúan la razón de ser del colectivo". Conviene llevar el papel como educadores hacia "una permanente reflexión colectiva del sentido de nuestra función como educadores". Resultará clave "pertenecer al colectivo docente", ya que "no podemos marchar solos. Necesitamos un gremio que nos apoye y luche por nuestros derechos"; "el papel como docente es fundamental en la formación ciudadana", incluso "más allá de los contenidos curriculares, debemos aportar espacios de discusión y diálogo crítico en torno a la libertad, los valores y las normas, para la creación de una sociedad plural, solidaria, democrática, comprometida con el medio natural y social". Si bien las presiones curriculares suelen dejarnos poco margen de actuación, conviene siempre apelar a un criterio responsable y participativo (Freedman, 2008).

\section{Del Atlántico al Pacífico}

Seguimos nuestro recorrido por las opiniones de docentes que encontramos ahora en el otro extremo del continente. La cordillera delimita el paisaje visual de Santiago de Chile, ubicada en el centro de un extenso país recorrido de norte a sur por el océano Pacífico y por los Andes. La historia reciente de Santiago y de Chile contiene una tremenda mancha de sangre y de dolor, un lamentable momento histórico provocado por la dictadura de Augusto Pinochet, un proceso contra la libertad que pudimos conocer, a pesar de la distancia, por la crueldad de los atropellos cometidos contra las personas. El territorio y la historia se dan aquí la mano para alentar a las jóvenes generaciones a mejorar y a seguir luchando por sus derechos. Las políticas económicas y urbanísticas neoliberales impulsadas por los conocidos como "Chicago Boys" han abierto nuevas y mayores brechas sociales que se unen a las que ya había anteriormente (Belil, Borja \& Corti, 2012). Hablamos con educadores de una ciudad que ha erigido un Museo de la Memoria y los Derechos Humanos que sirve de ejemplo a tantos otros países del mundo. Nos acercamos a la realidad educativa de una ciudad en la que el ambiente cultural es de gran calado y donde el nivel de reflexión de sus intelectuales y sus docentes sigue el ritmo valiente de una sociedad muy reivindicativa. No podemos dejar de exponer la importante tarea educativa (Augustowsky, 2012) que se desarrolla en enclaves culturales de Santiago como el Centro Cultural Palacio de la Moneda, el Museo de Arte Contemporáneo, el Museo de la Solidaridad Salvador Allende, el Centro Cultural Matucana 100 o el Museo Artequín, un ejemplo único de museo pensado para el público más joven (Huerta, 2010). Los docentes de aquí nos abren posibilidades de nuevas miradas hacia una ciudad y un país que viven en un proceso constante de reflexión y acción educativa.

Al indicar los aspectos negativos de Santiago, Catalina se refiere a la saturación manifiesta "en la cantidad de habitantes y en la proliferación de edificios altos donde, en el terreno de una casa familiar, se construye un edificio con 40 departamentos para 40 familias". Tampoco valora 
positivamente la irrupción de los malls (así llaman aquí a los centros comerciales o shoppings) en gran parte de la capital. El imaginario que nos transmite el profesorado chileno en los cuestionarios recogidos está impregnado de espacios seductores que mapean la ciudad, una urbe tremendamente contaminada, con brumas de contaminación (ellos lo denominan smog) que en ocasiones impiden ver los Andes. De hecho, cuando les pedimos a los docentes que describan aspectos destacables de su ciudad, en la mayoría de ocasiones aparece la cordillera como elemento incuestionable. O en su defecto los cerros ("la diversidad de montañas que rodea la ciudad"), especialmente el de San Cristóbal, que según muchos es el lugar idóneo para divisar toda la ciudad en un día claro: "es como un panóptico: da la ilusión de que puedes verlo todo y que estás sin estar en la ciudad; esa sensación es magnífica". También se valora la componente patrimonial del cerro de Santa Lucía, así como "el Cerro La Cruz, en el parque Mahuida, un lugar especial, un espacio realmente mágico, en donde puedes admirar tanto la belleza de la naturaleza como la apretada estructura de la ciudad". De hecho, "siempre hay magia cuando hay distancia, cuando se ve la ciudad desde un punto alejado y alto, se siente el ritmo, la sístole y la diástole, esa musicalidad que tiene en su conjunto", algo que ocurre "en la punta del cerro Manquehue o del cerro Renca".

Fotos 13,14 y 15

Imágenes de la capital chilena tomadas por docentes
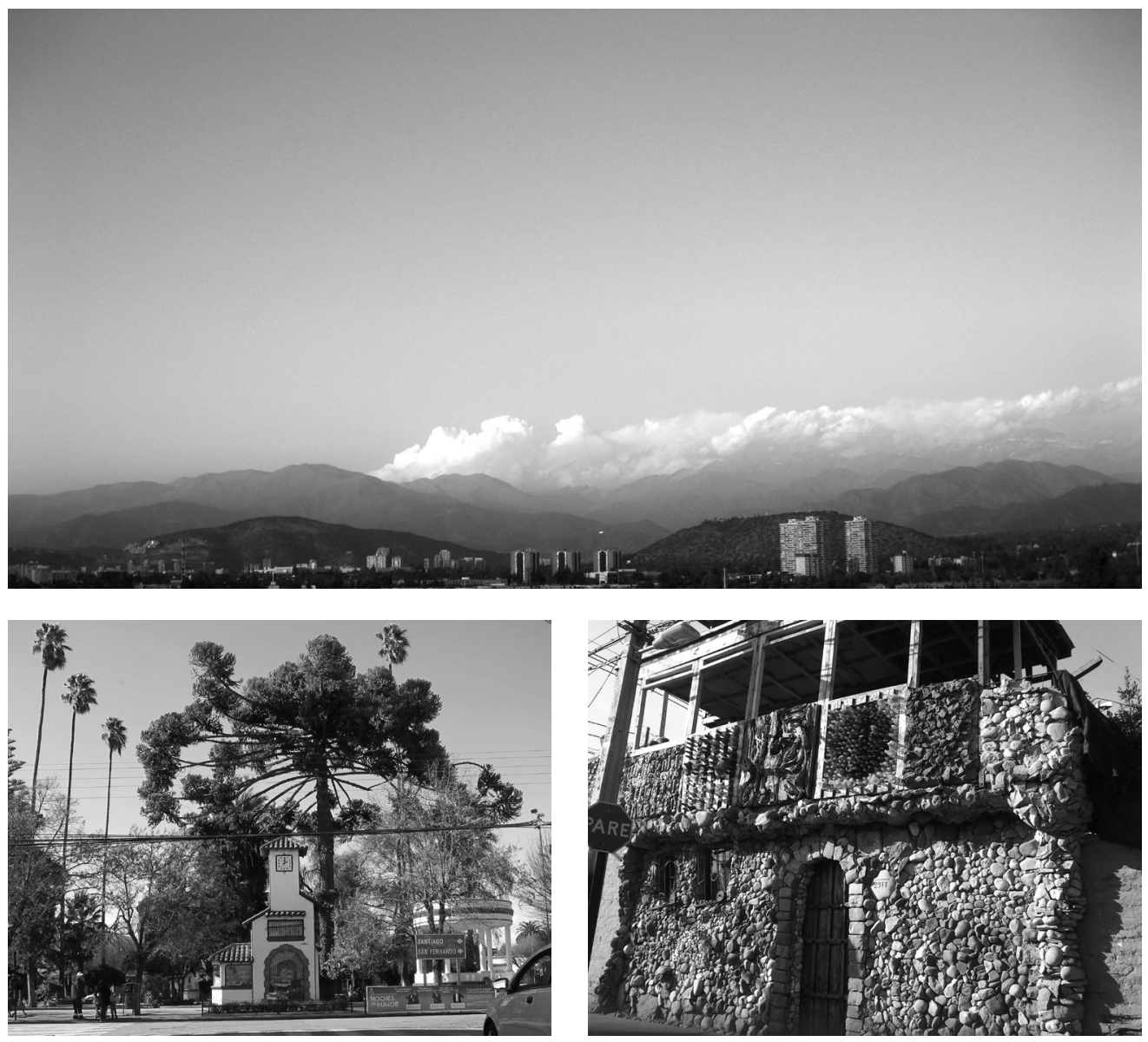

Fuente: Isabel Dávila, Daniela Castro y Carlos Valderrama 
Observamos que el profesorado chileno utiliza un discurso contundente al abordar los intereses del colectivo: "es importante pertenecer al colectivo de docentes, porque trabajar en red es mucho más potente que a nivel individual, se pueden obtener resultados más óptimos y masivos fomentando el trabajo de equipo, contrario al extremo individualismo que vivimos en la actualidad". Es fundamental "que exista una cohesión entre los docentes, indistintamente de su disciplina de origen; dicha cohesión debe permitir la conformación de grupos de colaboración, que generen una identidad docente, que defina el rol de los profesores y a su vez busque puentes de conexión interdisciplinarios que permitan a los alumnos ver la educación como algo universal y no sectorizado". De esa forma, "cada docente no compite con su asignatura sino que contribuye al desarrollo de los vínculos que se pueden generar con otras". Los docentes asumen su responsabilidad en lo referido a formación de ciudadanía. Están conscientes de que en la mayoría de ocasiones las barreras curriculares impiden realizar acciones innovadoras. El profesorado genera mitologías particulares sobre su propia ciudad. Estas mitologías en ocasiones pueden estar impregnadas de lo que el propio profesorado transmite al alumnado durante las clases. En cualquier caso, llama la atención la falta generalizada de una mejor formación en artes. Las pocas nociones sobre urbanismo o arquitectura influyen decisivamente en el modo de percibir la ciudad y, por tanto, resultarán precarias a la hora de transmitir esa percepción. Y si bien la educación es un factor de progreso, en el caso de Chile estamos hablando de un país con un modelo muy criticado, algo que ha provocado movilizaciones masivas y contundentes en los últimos años y ha convertido a este lugar del mundo en un referente internacional por la lucha de los derechos a una educación equitativa y digna para todas las personas.

Más de diez millones de personas habitan la capital del Perú. A su posición estratégica, por limitar con el mar y por disponer uno de los puertos clave de Sudamérica, se une su alto valor patrimonial. Solamente en la ciudad de Lima se registran 600 yacimientos arqueológicos, algunos de ellos recientemente recuperados para la ciudadanía y para las visitas de los turistas, como el espectacular recinto de Mateo Salado. Este tipo de lugares, habitualmente antiguos espacios sagrados, son conocidos aquí como "huacas". Una de las características que visualmente definen Lima es la gran expansión que ha vivido la ciudad en las últimas décadas. A los asentamientos humanos que ocupan los vastos territorios periféricos aquí se les denomina "invasiones". El aluvión humano que llegó a la ciudad huyendo de la violencia en los campos se asentó en estas zonas que colindan con los márgenes del entramado urbano. En los últimos años se está potenciando la construcción de edificios de excesivas alturas, algo difícil de entender en una zona de alto nivel sísmico. Hemos comentado que esta tendencia se observa también en el vecino Chile, donde los tradicionales barrios con casas de una sola altura ven florecer (como "champiñones", dicen aquí) grandes edificios de viviendas, auténticos rascacielos que rompen el skyline tradicional de este tipo de ciudades. Hay conciencia de la falta de criterio en el ordenamiento de los transportes urbanos, si bien desde la municipalidad se verifica un trabajo importante para mejorarlo. Se critica la pobreza reinante entre la mayoría de la población, provocada por las grandes brechas sociales que separan a ricos y pobres. Inciden en que hay algunos lugares descuidados, sucios, y que esto afecta la conservación del patrimonio (en 1988 Lima fue declarada por la UNESCO ciudad patrimonio de la humanidad). La imagen que escogemos para reproducir aquí (foto 16) dice mucho del conjunto recopilado, ya que en ella domina el gris al tiempo que retrata un mar de edificios, y evita un posible apego hacia lo turístico. De hecho, el profesorado da importancia a "las vistas" de su ciudad desde la propia vivienda que habita. 


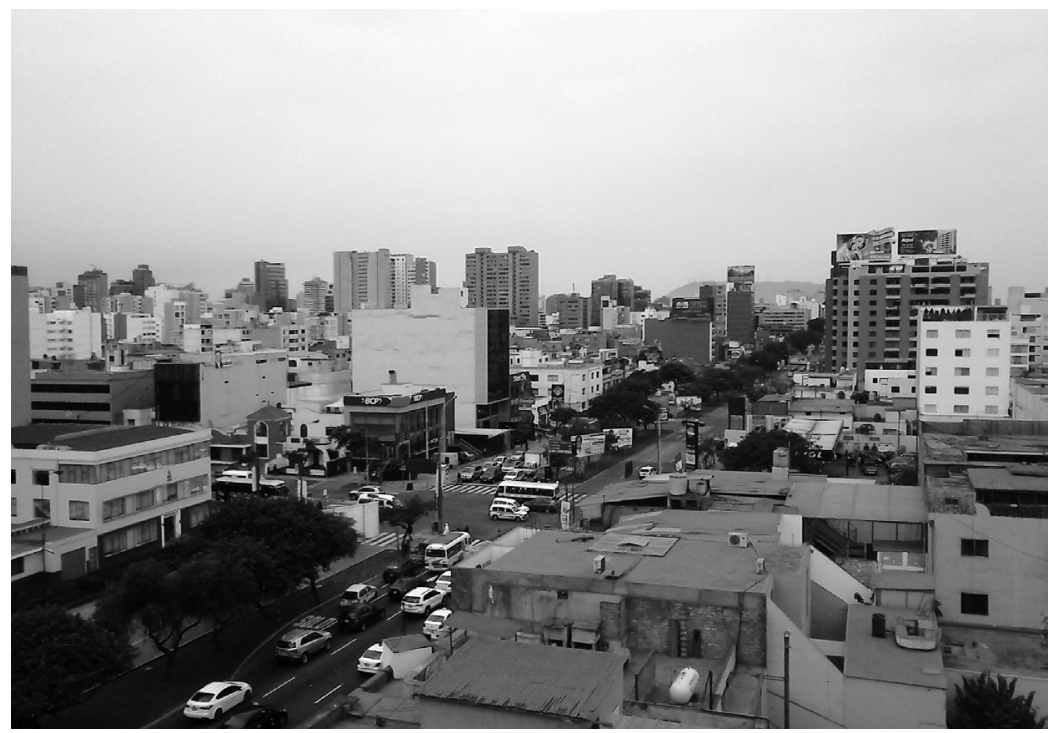

Fuente: Romina Ridella

Les preguntamos por un escritor o escritora y destaca con el $70 \%$ de contestaciones Mario Vargas-Llosa, el premio Nobel peruano que con su novela La ciudad y Los perros se sitúa entre los más admirados o conocidos. Les preguntamos por un elemento patrimonial de la ciudad y nos llama la atención que nadie cite el espectacular Cementerio Museo General Presbítero Matías Maestro, ni tampoco la recientemente inaugurada al público Huaca de Mateo Salado, dos piezas particularmente únicas y espectaculares de la ciudad. Los lugares patrimoniales que aparecen en sus comentarios son la huaca Pucllana, la huaca Pachacámac, y el complejo arqueológico Maranga, como escenarios de las culturas preincaicas, mientras que la catedral de Lima, el palacio Arzobispal y la Iglesia de San Francisco (con sus catacumbas) serían los elementos patrimoniales más citados del repertorio religioso católico. La Plaza de Armas, las casonas limeñas y en general el centro histórico también se valoran, así como una serie de elementos de orden inmaterial como la bandera, los pregones o la cultura chicha. Cuando escriben sus textos inciden en redactar sobre los entornos patrimoniales al uso (de carácter más turístico), pero al crear imágenes se desplazan hacia sus espacios vivenciales, para dar importancia a su mirada cotidiana.

Lucía reconoce "la importancia de formar niños con valores que respeten su propia identidad y conozcan que son parte de una diversidad cultural, fomentando espacios y visitas que acerquen más al niño directamente con su ciudad y a su vez que conozca las demás ciudades del Perú". Carola entiende que el papel que ejerce como docente es muy importante en la formación de ciudadanía, ya que "el alumnado debe sentirse identificado con el lugar donde vive, para que así puedan interesarse más por su historia y enseñar a las demás personas". Belén valora mucho el papel del docente en general "como encargados conjuntamente con la familia y el Estado peruano de brindar una buena educación cívica y ciudadana". Karen considera su papel como futura docente "de suma importancia, ya que los niños y los jóvenes son partícipes de la ciudad, por ende, se debe educar para el buen ejercicio ciudadano, para la convivencia". Lima es de por sí una ciudad fascinante, pero vamos más allá 
y les preguntamos a las maestras si para ellas hay un lugar realmente mágico que destacarían del conjunto. Para algunas es el Puente de los Suspiros, situado en el distrito de Barranco, como en el caso de Belén a quien le gusta el lugar porque le hace "pensar en gente de la época, en mujeres con vestidos largos esperando a alguien". Otras prefieren el Malecón, especialmente la parte de Miraflores, como Romina a quien le gusta "hacer caminatas y deporte a cualquier hora del día", y que destaca su plaza principal con la Iglesia Virgen Milagrosa, rodeada del espectacular parque Kennedy, ya que "es un distrito lleno de vida, tanto por su actividad comercial, como por los restaurantes y los bares clásicos del distrito", y porque permanece "la vida de barrio, los vecinos tenemos todo a la mano y caminando se puede llegar a cualquier lugar del distrito". A Sara le gusta Miraflores porque en Bajada Balta se practica parapente. El Parque de las Aguas es citado en seis ocasiones, y algunos parajes naturales como el "acantilado de la Costa Verde en donde se puede apreciar el atardecer sobre todo en el verano" y que "está frente al mar y es donde se siente la tranquilidad y la paz, sin tener que irse fuera de la ciudad". Estas son las opiniones reflejadas en los textos, sin embargo, al aportar imágenes, optan por fotografiar los lugares en los que viven o trabajan, lo cual demuestra en qué lugar se encuentran sus verdaderos intereses.
Precisamente, entre el Atlántico y el Pacífico se sitúa Colombia, inmenso país de excesos e intensidades. Las acciones de recogida de datos para nuestro estudio se realizaron en 2016. Ese mismo año aparece el manifiesto "Las mujeres y las niñas, declaramos que la paz también es nuestra", un documento que reivindica el papel esencial que deberían tener las mujeres en la solución a un conflicto que viene azotando el país desde hace cinco décadas. Leemos en él que "esta guerra solamente ha servido para generar sufrimiento a una gran parte de la población colombiana". La violencia ha provocado muchísimo dolor en el país, un dolor interiorizado que sigue atenazando la libertad en todos los sentidos, algo que afecta al conjunto de la población, y especialmente a las mujeres. No perdamos de vista que el colectivo docente ha sido el más afectado y con más muertos durante el conflicto, como queda reflejado en una de las instalaciones del Museo Casa de la Memoria de Medellín ("entre 1991 y 2012 fueron asesinados 900 docentes en Colombia"). Durante las sesiones de recogida de datos, tuvimos la oportunidad de plantear una acción performativa en la que se dejó constancia de la presencia del dolor y de la memoria del conflicto. En las imágenes siguientes vemos un momento de la acción, que se inició escenificando un abrazo (recordando la obra El abrazo, de 1976, del artista

Fotos 17,18 y 19

Acciones performativas llevadas a cabo con docentes de Medellín
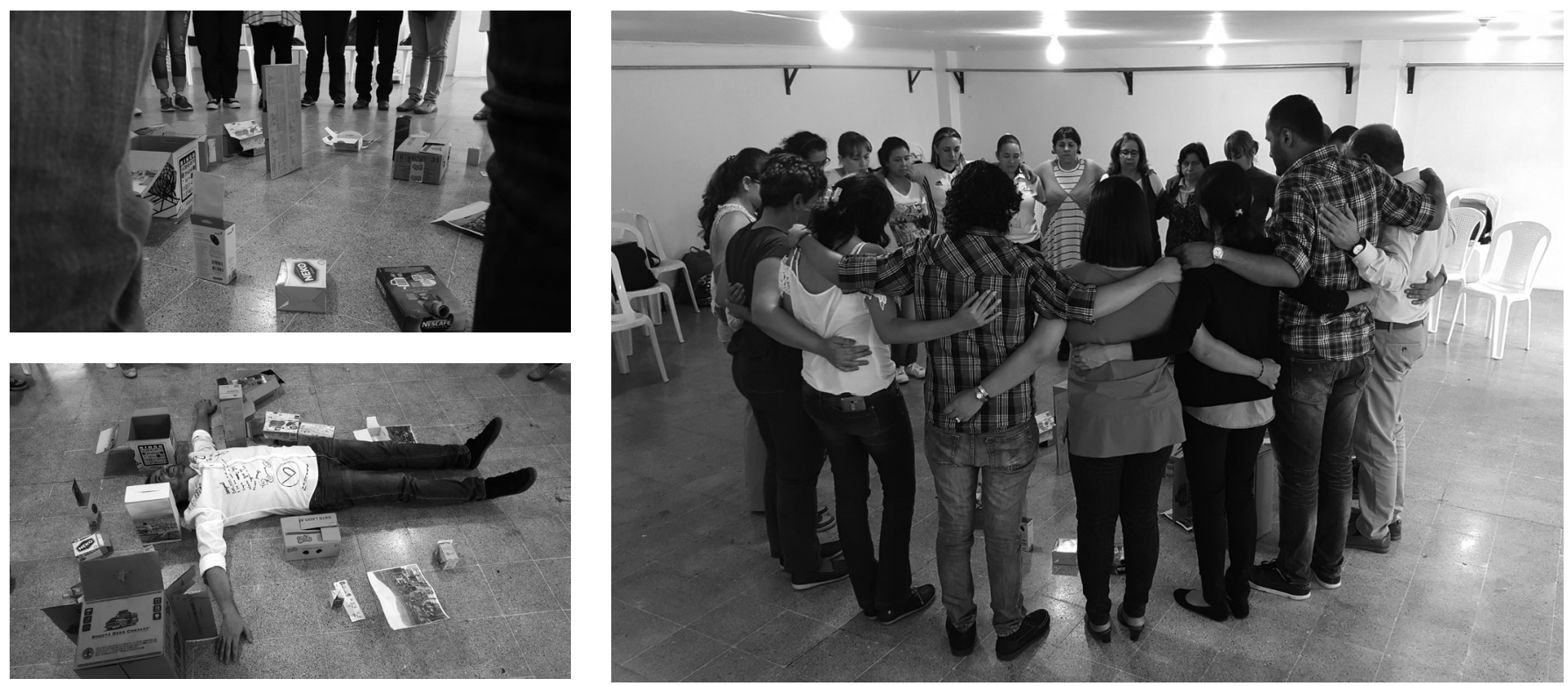

Fuente: elaboración propia 
Fotos 20,21 y 22

Imágenes de Medellín aportadas por docentes a las sesiones


Fuente: docentes de Medellín

Juan Genovés), y donde no faltaron ni la selección ni los comentarios de imágenes traídas por los maestros, así como la construcción de una ciudad a partir de objetos y cajas que traen quienes participan.

Al explicar las fotografías, pudimos escuchar relatos de extrema dureza. Una de las participantes explicó que vio cómo morían los padres de su compañera del colegio cuando era niña, al estallar un explosivo en el Parque San Antonio, en la carrera 46 con calle 47, al lado de la escultura El pájaro, de Fernando Botero (lo que supuso 20 muertos y 99 heridos). Eso ocurría el 10 de junio de 1995 en el centro de la capital antioqueña, en plena zona comercial. Este relato surgió porque una maestra había traído precisamente una fotografía de la escultura El pájaro. Prácticamente, todos los docentes podían explicar situaciones delicadas y momentos de gran tensión que habían sufrido a lo largo de sus vidas. Las aparentemente imágenes inocuas revelaron después su gran potencial para ayudar a relatar y explicar vivencias conflictivas (Huerta, 2017). Quienes intervenían en la actividad se sorprendieron de la capacidad sugeridora que llevaban esas fotografías por el hecho de retratar espacios urbanos donde había habido tensiones y se habían vivido auténticos dramas. 
Foto 23

Panorámica de Medellín incorporada a la investigación por un docente

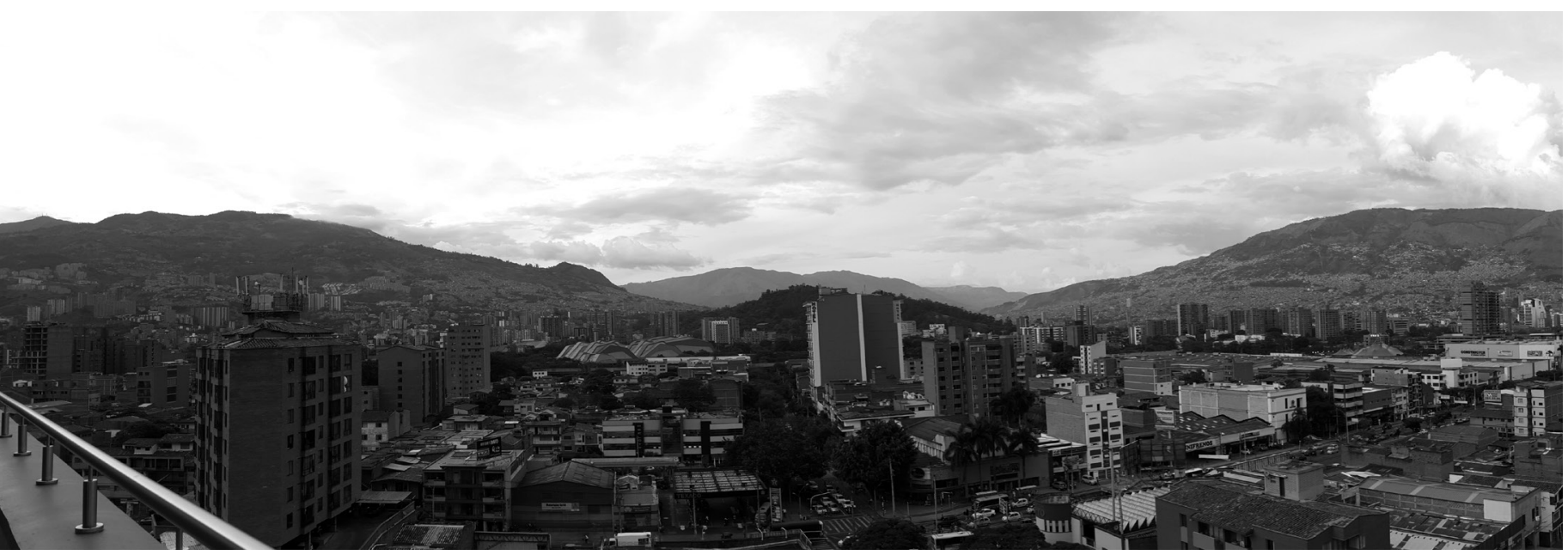

Fuente: docente de Medellín

El interés por las cuestiones que ha generado el conflicto se mantiene vivo; en el ámbito de la investigación educativa, numerosas voces desde diferentes ámbitos mantienen la tensión para sugerir nuevos enfoques o aclarar cuestiones poco tratadas. Al indagar en las representaciones del conflicto colombiano en los libros de texto, estudios recientes nos animan a tomar datos de quienes lo han sufrido en directo:

"Es cierto que para transformar el presente se debe mirar la heterogeneidad de perspectivas hacia el pasado, de lo que ha sucedido tanto en el ámbito nacional como en el local. Aquí, las experiencias individuales deberían tenerse en cuenta en el marco de los antecedentes del conflicto social del país". (Duque-Gómez, 2017, p. 63)

El interés del municipio de Medellín por impulsar una mayor reflexión hacia el colectivo docente tiene ejemplos concretos en algunas iniciativas como la Casa del Maestro o la nueva etapa del MOVA Centro de Innovación del Maestro. Se van dando pasos para potenciar una mayor presencia de maestros en las distintas actividades que se programan. $Y$ si bien es cierto que las heridas cicatrizan al darle tiempo al tiempo, en cualquier caso no podemos dejar que se silencien las voces de quienes han vivido y padecido en directo los abusos del conflicto. Una manera de despojar el dolor es hablar del propio sufrimiento. Este mecanismo de introspección se puede articular también mediante imágenes, realizando fotografías y videos en los que se expresen todo tipo de mensajes interiorizados.

Recogemos entre las opiniones del profesorado colombiano aspectos contrastados, ya que si por un lado se muestran muy cautos ante determinadas cuestiones vinculadas al pasado reciente, al mismo tiempo observamos un gran deseo por dejar constancia de experiencias vividas. José Luis Medina-Moya (2017), recuperando las ideas de Friedrich Schleiermacher, insiste en que el análisis de datos cualitativos (ADC) "debería ayudar al investigador a recrear en su mente el mundo interior del otro", ya que "el énfasis se pone en acceder al proceso interno de confección de una idea o 


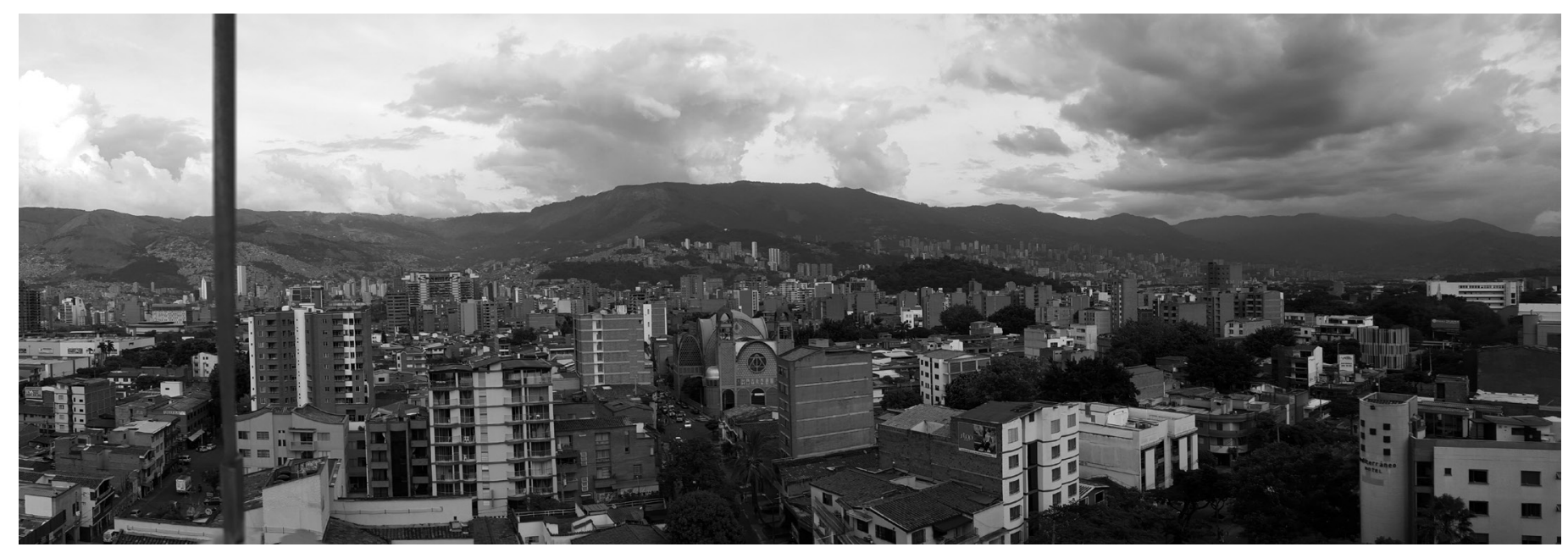

de una acción: comprender es reproducir el sentido de la vivencia que el hablante quiso designar con sus palabras". Por ello encontramos decisivo poder acercarnos a cada una de las voces que analizamos, puesto que "la buena interpretación de un dato (un relato, una observación) sería la que el autor podría aprobar, dado el contexto", y en ese sentido "el análisis de datos cualitativos presupone la inversión de un acto de habla: interpretar es una reconstrucción" (Medina-Moya, 2017, p. 46). En nuestro caso, además, las imágenes son capaces de transmitir nuevos aspectos significativos que hasta ahora solamente podíamos entrever por medio de las palabras y del discurso verbal. Ahora, las imágenes modulan interpretaciones complejas y sutiles.

En las fotografías realizadas por el profesorado colombiano ocurre lo mismo que hemos detectado en el resto de países: sus imágenes reflejan la cotidianidad. Es decir, lo que realmente les apasiona es contar fotográficamente sus vivencias, para mostrar así sus escenarios habituales y evitan por tanto generar una postal turística de su propia ciudad. Lo más Ilamativo en el caso de las aportaciones del profesorado de Medellín es que a pesar de haber vivido situaciones de gran dificultad, y habiendo superado etapas complicadísimas, las ganas y el deseo de conseguir una convivencia viable y efectiva se mantienen en cada una de sus expresiones, tanto verbales como icónicas. La preocupación por conseguir una sociedad más justa y equilibrada está en la línea de lo que argumentan F. Javier Murillo y Cynthia Martínez-Garrido cuando denuncian los altos niveles de segregación socioeconómica, étnicocultural y por procedencia inmigrante/ nativo que existe en los países de Latinoamérica, con "unos índices de segregación escolar muy altos, inaceptables, posiblemente los más altos del mundo", sugiriendo que "Si queremos sociedades más igualitarias, más justas e inclusivas, tenemos que empezar por hacer nuestros sistemas educativos más justos e inclusivos. No hay atajos" (Murillo \& Martínez-Garrido, 2017, p. 27).

\section{Conclusiones}

Habiendo podido escuchar los relatos de docentes en varias ciudades de Iberoamérica, comprobamos que el interés por el patrimonio y el legado cultural urbano es muy alto entre los profesionales de la enseñanza. La responsabilidad de construir con esfuerzo una nueva ciudadanía y el deseo de conseguir un entorno más propicio para las nuevas generaciones son motivos estimulantes y metas planteadas por el conjunto de docentes con que hemos desarrollado la investigación. Además, el contacto con la realidad urbana ofrece numerosos espacios de reflexión, lo cual permite establecer un diálogo entre docentes y discentes más allá de las diferencias que pueda haber entre ambos. Hemos destacado aquí algunos resultados concretos, utilizando unas pocas imágenes de cada entorno analizado, para seleccionar una muestra concreta de cada lugar y comprobar que al crear imágenes los docentes no funcionan como turistas en su propia ciudad, sino que eligen escenarios problematizantes para representarla. 
Es importante valorar lo que piensan y viven los alumnos de los recintos educativos, especialmente aquellos más desprotegidos, pero no podemos olvidar lo que opinan los docentes. Nuestra investigación se centra en el profesorado (les animamos a crear imágenes, a revisar los contrastes de su propia ciudad), pero en el futuro cada docente podrá llevar al aula este mismo esquema de trabajo, para potenciar el uso educativo de imágenes creadas por su alumnado. Los maestros acceden con gusto y entusiasmo a redescubrir su propia ciudad. Al fotografiarla y compartir las imágenes de los rincones que les interesan desentrañan significados en los que antes no se habían fijado. Optan por implicarse con más energía por todo aquello que supone compartir problemáticas con el resto de docentes. En cualquier caso, detectamos que la mirada del profesorado hacia la ciudad es activa, crítica y enriquecedora, lo cual nos obliga a tener en cuenta esta visión, ya que el colectivo docente tiene que asumir muchas de las premisas que hace unas décadas se les exigían a los intelectuales.

El profesorado tiene ahora la palabra. Cuando escuchamos sus voces y revisamos sus imágenes aparecen constantes que nos ayudan a detectar aquello que realmente desean: una profesión más valorada y un mayor respeto hacia su trabajo; unas ciudades más habitables en las que los conflictos se solucionen mediante el diálogo; un alumnado más reflexivo y crítico capaz de reivindicar mejoras; una ciudadanía emprendedora y valiente que sepa afrontar con valentía los retos más urgentes. Al valorar positivamente sus imágenes les brindamos una nueva manera de expresar sus ideas. No estudiamos exclusivamente los resultados como hechos artísticos o estéticos, sino que celebramos los mensajes gráficos del colectivo docente como poéticas de la subversión. Las fotografías y los videos del profesorado contienen un nuevo modelo de mensaje, ya que las imágenes nos trasladan con nitidez hacia todo aquello que les resulta más interesante. Al utilizar esta afluencia de miradas, comprendemos lo mucho que tienen por decir las personas que configuran el complejo tejido de la profesión docente. Creemos que es posible motivar al profesorado al valorar las imágenes que crean de su entorno urbano vivido. Lo hacemos desde el compromiso y la tolerancia, para activar un empoderamiento emotivo que, al mismo tiempo, visibiliza sus deseos y deja constancia de sus problemáticas.

\section{Sobre el autor}

Ricard Huerta es profesor de educación artística en la Universitat de València. Director de EARI Educación Artística: Revista de Investigación. Ha sido investigador invitado en universidades de Reino Unido, Francia, Italia, Colombia,
Argentina, Perú, Chile, Uruguay y Ecuador. Su interés por las identidades y los patrimonios lo ha llevado a la publicación de textos e intervenciones artísticas en museos y centros de arte. Sus últimos libros publicados son La ciudad y sus docentes, miradas desde el arte y la educación (Barcelona: Editorial de la Universitat Oberta de Catalunya, UOC, 2015) y Transeducar. Arte, docencia y derechos LGTB (Madrid: Egales, 2016).

\section{Referencias}

Alderoqui, Silvia (2012). Paseos urbanos. El arte de caminar como práctica pedagógica. Buenos Aires: Lugar Editorial.

Augustowsky, Gabriela (2012). El arte en la enseñanza. Buenos Aires: Paidós.

Barreira, Irlys \& Mattos, Geísa (2014). The City as an Object of Research: Microsociology of Urban Spaces in Brazil. Current Urban Studies, 2, $127-$ 139. DOI: $10.4236 /$ cus.2014.22013

Belil, Mireia; Borja, Jordi \& Corti, Marcelo (eds.) (2012). Ciudades, una ecuación imposible. Barcelona: Icaria.

Benjamin, Walter (2005). Libro de los pasajes. Madrid: Akal.

Bustamante-Cardona, Bernardo (2016). Aproximación a una re-conceptualización de la educación artística en la sociedad del conocimiento en Colombia. Revista Gearte, 3 (2), 151-161. Disponible en: http://seer.ufrgs.br/index.php/gearte/article/ download/64798/38575

Bustamante-Zamudio, Guillermo (2016). Sobre el concepto de campo en Bourdieu. magis, Revista Internacional de Investigación en Educación, 9 (18), 49-66. DOI: 10.11144/Javeriana.m9-18. sccb. Disponible en: http://revistas.javeriana.edu. co/index.php/MAGIS/article/view/18062/pdf

Calvino, Italo (2010). Le città invisibili. Milano: Mondadori.

Careri, Francesco (2002). Walkscapes. El andar como práctica estética. Barcelona: Gustavo Gili.

Careri, Francesco (2014). Walkscapes diez años después. URBS Revista de Estudios Urbanos y Ciencias Sociales, 4 (1), 207-213. Disponible en: https://dial net.unirioja.es/servlet/articulo?codigo $=4718671$

Charlone, César \& Fernández, Enrique (2007). El baño del Papa. Uruguay, Brasil, Francia: Laroux Cine, 02 Filmes, Chaya Films, Telelmage, Francisco Salomón \& Hugo Kovenski.

Codeluppi, Vanni (2014). Metropoli e luoghi del consumo. Milano: Mimesi.

Duncum, Paul (2008). Holding Aesthetics and Ideology in Tension. Studies in Art Education, 49 (2), 122-135.

Duque-Gómez, Luisa Fernanda (2017). Conflicto social colombiano: representación en textos escolares de ciencias sociales. magis, Revista Internacional de Investigación en Educación, 9 (19), 49-68. 
DOI: 10.11144/Javeriana.m9-19.cscr. Disponible en: http://revistas. javeriana.edu.co/index.php/MAGIS/article/view/18611/pdf

Edwards, Elizabeth (2014). Photographic Uncertainties: Between Evidence and Reassurance. History and Anthropology, 25 (2), 171-188.

Errázuriz, Luis Hernán (2006). Sensibilidad estética. Un desafío pendiente en la educación chilena. Santiago de Chile: Pontificia Universidad Católica de Chile, PUC.

Freedman, Kerry (2008). Leading Creativity: Responding to Policy in Art Education. En Teresa Eça \& Rachel Mason (eds.). International Dialogues about Visual Culture, Education and Art, 39-47. Bristol: Intellect.

Giroux, Henry (1990). Los profesores como intelectuales. Hacia una pedagogía crítica del aprendizaje. Barcelona: Paidós.

Guimarães, Leda Maria de Barros (2017). A pregunta que foi feta: sobre escolhas metodológicas e desafíos na pesquisa em arte e cultura visual. En Fernando Miranda, Gonzalo Vicci \& Melissa Ardanche (comps.). Educación y visualidad. Investigaciones pedagógicas en contextos hiper visuales, 137-144. Montevideo: Universidad de la República, Udelar.

Hubard, Olga M. (2008). The Act of Looking: Wolfgang Iser's Literary Theory and Meaning Making in the Visual Arts. International Journal of Art and Design Education, 27 (2), 168-180. DOI: 10.1111/j.14768070.2008.00572.x

Huerta, Ricard (2010). Un proyecto de investigación en educación artística: aspectos identitarios de las maestras chilenas. Pulso, 33, 31-59. Disponible en: http://roderic.uv.es/bitstream/handle/10550/33820/060995. pdf? sequence $=1$ \&isAllowed $=\mathrm{y}$

Huerta, Ricard (2012). Mujeres maestras. Identidades docentes en Iberoamérica. Barcelona: Graó.

Huerta, Ricard (2014). La mirada de los docentes hacia su ciudad: identidades urbanas y educación patrimonial. Pulso, 37, 127-147. Disponible en: https://ebuah.uah.es/dspace/bitstream/handle/10017/21145/Mirada\%20Huerta.pdf?sequence $=1$

Huerta, Ricard (2015). La ciudad y sus docentes. Miradas desde el arte y la educación. Barcelona: Editorial de la Universitat Oberta de Catalunya, UOC.

Huerta, Ricard (2017). La ciudad educadora y sus docentes. Experiencias alrededor del mundo. Bogotá: Editorial Magisterio.

Huerta, Ricard \& Calle, Romà de la (eds.) (2013). Patrimonios migrantes. Valencia: Publicacions de la Universitat de València, PUV.

Irwin, Rita L. \& O'Donoghue, Dónal (2012). Encountering Pedagogy through Relational Art Practices. International Journal of Art \& Design Education, IJADE, 31 (3), 221-236. Disponible en: http:// reheardregalement.com/wp-content/uploads/2014/06/donalandri taonsummerhill.pdf

Laddaga, Reinaldo (2006). Estética de la emergencia. La formación de otra cultura de las artes. Buenos Aires: Adriana Hidalgo Editora.

Lynch, Kevin (1998). La imagen de la ciudad. Barcelona: Gustavo Gili.

Maffesoli, Michel (2000). Le temps des tribus. Le déclin de l'individualisme dans les sociétés postmodernes. Paris: La table ronde.

Martínez-Bonafé, Jaume (2014). La ciudad como contenido del currículo. Cuadernos de Pedagogía, 447, 81-83.

Masschelein, Jan (2006). E-ducar la mirada. La necesidad de una pedagogía pobre. En Inés Dussel \& Daniela Gutiérrez (comps.). Educar la mirada. Políticas y pedagogías de la imagen, 295-310. Buenos Aires: Manantial. Disponible en: http://nuestraescuela.educacion.gov.ar/ bancoderecursos/media/docs/apoyo/apoyo04.pdf 
Medina-Moya, José Luis (2014). El proceso de comprensión en el análisis de datos cualitativos en educación. magis, Revista Internacional de Investigación en Educación, 7 (14), 39-54. Disponible en: http://revis tas.javeriana.edu.co/index.php/MAGIS/article/view/11855/pdf_1

Méndez-Rivera, Pilar (2016). Constitución de sujeto maestro en prácticas de resistencia en Colombia. Enunciación, 21 (1), 15-30. Disponible en: https://www.academia.edu/29784024/Constituci\%C3\%B3n_de_su jeto_maestro_en_pr\%C3\%A1cticas_de_resistencia_en_Colombia

Morphy, Howard \& Perkins, Morgan (eds.) (2006). The Anthropology of Art. A Reader. Oxford: Blackwell.

Muntañola, Josep \& Muntañola, Dafne (2011). La sociología del espacio al encuentro de una arquitectura oculta en la educación. Revista de Sociología de la Educación, RASE, 4 (2), 133-151. Disponible en: https:// ojs.uv.es/index.php/RASE/article/view/8299

Murillo, F. Javier \& Martínez-Garrido, Cynthia (2017). Estimación de la magnitud de la segregación escolar en América Latina. magis, Revista Internacional de Investigación en Educación, 9 (19), 11-30. DOI: 10.11144/Javeriana.m9-19.emse. Disponible en: http://revistas.jave riana.edu.co/index.php/MAGIS/article/view/18608/pdf

Ordine, Nuccio (2013). La utilidad de lo inútil. Barcelona: El Acantilado.

Pamuk, Orhan (2009). Estambul. Ciudad y recuerdos. Barcelona: Mondadori.

Pariser, David; Castro, Juan Carlos \& Lalonde, Martín (2016). Mobilities, Aesthetics and Civic Engagement: Getting At-Risk Youth to Look at their Communities. International Journal of Education through Art, 12 (2), 211-225. http://dx.DOI.org/10.1386/eta.12.2.211_1

Planella-Ribera, Jordi (2014). El oficio de educar. Barcelona: Editorial de la Universitat Oberta de Catalunya, UOC.

Rebella, Juan Pablo \& Stoll, Pablo (dirs.). (2004) Whisky. Argentina, Alemania y España: Control Z Films, Rizoma Films, Wanda Visión \& Pandora Filmproduktion.

Robalino-Campos, Magaly (2014). Políticas públicas integrales e intersectoriales para el desarrollo de la profesión docente: un tema pendiente en América Latina. Educación y Ciudad, 27, 89-99.

Romano, Marco (2008). La città come opera d'arte. Torino: Giulio Einaudi Editore.

Rose, Gillian (2016). Visual Methodologies: An Introduction to Researching with Visual Materials. London: Sage Publications.

Sassen, Saskia (2011). Strategic Geographies. Challenge of their Visualization. En Chantal Pontbriand (ed.). Mutations - Perspectives on Photography, 34-46. Göttingen: Steidl.

Sennett, Richard (2013). El artesano. Barcelona: Anagrama.

Stake, Robert E. (1998). Investigación con estudio de casos. Madrid: Morata.

Stenhouse, Lawrence (1987). La investigación como base de la enseñanza. Madrid: Morata.

Walker, John A. \& Chaplin, Sarah (2002). Una introducción a la cultura visual. Barcelona: Octaedro. 